\section{SOI: 1.1/TAS DOI: $10.15863 / \mathrm{TAS}$ International Scientific Journal Theoretical \& Applied Science}

p-ISSN: 2308-4944 (print)

e-ISSN: 2409-0085 (online)

Year: 2015

Issue: 09

Volume: 29

Published: 30.09 .2015

http://T-Science.org
Abbas Mohsin Salman Al- Hameedawi

Professor

College of Agriculture, University of Kufa

Iraq

ali.alhameedawi@uokufa.edu.iq

SECTION 23. Agriculture. Agronomy. The technique.

\title{
RESPONSE OF LOCAL APPLE TREES TO SPRAYING WITH GROFALCS ,STAVALS AND TALL-PROLONG ON PHYSICAL AND CHEMICAL CHARACTERISTICS OF FRUITS
}

\begin{abstract}
This study was carried out on privat orchard at AL-Abbasyia. Najaf for season 2014 on the local apple fruit cv. Sharaby. The trees were spraying with three concentration of Grofalcs (200, 300 and 400) $\mathrm{mg} / \mathrm{L}$, Stavals (100, 200 and 300) $\mathrm{mg} / \mathrm{L}$ and Tall-Prolong (1,2 and 3)\% after 60 days from full bloom stage. Fruits were picked after 95 days from full bloom. The result indicated that leaf aria, total chlorophyll, shoot length, length, diameter, weight, firmness, Calcium pictate and humidity of fruits in creasing with increase concentration of Grofalcs, Stavals and Tall-Prolong. Also reduced percentage of fruit drupe, percentage of cracking, T.S.S , acidity and Vitamin $C$ of fruits in maturity stage. There was significant differences between these treatments. The concentration of Grofalcs $400 \mathrm{mg} / \mathrm{L}$ gave the best results on length, diameter, weight, firmness and cracking of fruits for the season of treatment respectively.

Key words: Grofalcs, Stavals and Tall-Prolong, physical and quality of apple fruits .

Language: English

Citation: Al-Hameedawi AM (2015) RESPONSE OF LOCAL APPLE TREES TO SPRAYING WITH GROFALCS, STAVALS AND TALL-PROLONG ON PHYSICAL AND CHEMICAL CHARACTERISTICS OF FRUITS. ISJ Theoretical \& Applied Science 09 (29): 72-75.

Soi: http://s-o-i.org/1.1/TAS-09-29-16 Doi: crossef http://dx.doi.org/10.15863/TAS.2015.09.29.16
\end{abstract}

\section{Introduction}

AL-Hamdawi [10] found that spraying trees of fig cv. Waziri wit h Grofalcs at conc. Of 250 $\mathrm{mg} /$ Lat 15 march for the tow growing seasons caused a significant increased total chlorophyll in leaves, total yield of tree, total soluble solids, vitamin $\mathrm{C}$, and fruit firmness and decrease in fruit fall, fruit cracking percentage compared with control treatment. ALShmery [7] noticed that, spraying the local apple trees cv. Red summer with three concentrations of $\operatorname{NAA}(50,75$ and 100$) \mathrm{mg} / \mathrm{L}, \mathrm{GA} 3(100,125$ and 150 ) $\mathrm{mg} / \mathrm{L}$ after 50 days from full bloom stage and picked fruits after 120 days from full bloom, there was a significant indicated that length, diameter, weight , firmness and humidity of fruits increased with increase concentration of NAA, GA3, also these treatments reduced the percentage of cracking, dropping, T.S.S, acidity and Vitamin C of fruits. AL - Ebraheme [3] noticed that, spraying apple c.v. Read summer tress with two concentration of NAA (25 and 50) $\mathrm{mg} / \mathrm{L}$, and castor oil (2 and 4)\% and combination treatment between them produced increasing significant in the moisture peels, pulp, juice percentage and reducing the cracking, T.S.S, acidity, anthocyanine on peels and vitamin $C$ in juice during fruits ripening. $\mathrm{AL}$ - Noumani [12] found that spraying local apple after 50 days from full bloom with Grofalcs at conc. of (200, 300 and 400) $\mathrm{mg} / \mathrm{L}$ led to reduction in percentage of fruit dropping and cracking and increased total soluble solids, total sugar, vitamin $\mathrm{C}$ and firmness at ripening . Singh [16] noticed that, spraying pomegranate trees with GA3 solution conc. of $200 \mathrm{mg} / \mathrm{L}$ demonstrated effectiveness in reducing fruit cracking and caused an increase in leaf total chlorophyll contents, total carbohydrates percentage in fruits , fruits firmness, and a decrease in fruit cracking percentage compared to control treatment. Byers and Carbough [13] found that, the addition of GA3 $150 \mathrm{mg} / \mathrm{L}$ to apple trees $\mathrm{cv}$. Styman has reduced the proportion of fruit cracking to $7 \%$ compared with $26.0 \%$ in the fruit of control treatment. Al- Dulaimi [2] stated that , spraying pomegranate trees cv. Salami by GA3 at conc. of 200 mg/L three times on 1996 and 1997 growing seasons, the interval between sprays was 30 days started from June at maturation, there was a significant decline in 
the proportion of fruit cracking for the medium concentration of the above nutrients as well as, increased constent of fruit epicarp of these nutrients compared with control treatment. AL- Rawi [4] noticed that, the spraying of GA3 concentration (50 and $100 \mathrm{ppm}$ ) on fig trees cv. Aswod Diala at depressed period reduced the proportion of fruit cracking and increased the firmness, leaf area , total chlorophyll, percentage of carbohydrate . Abo Zaid [1] mentioned that, spraying of GA3 at conc. of (100 and $150 \mathrm{ppm}$ ) on pear trees in Egypt has increased the vegetative growth and fruit firmness. This present study came to be a series of scientific research to assess spraying of Grofalcs, Stavals and Tall-Prolong on physical and chemical characteristics of local apple fruits cv. Sharaby during ripening .

\section{Materials and methods}

This study was conducted in a privat farm at AL-Abbasyia . Najaf governorate for the 2014 season on apple trees cv. Sharaby, 30 at same size and growth trees were selected with 15 years of age, that planted on $(5 \times 5 \mathrm{~m}$.), they were spraying with three concentration of Grofalcs ( It were discs of GA3 $50 \%$ from the production of Green river company . India ) $(200,300$ and 400) mg/L, Stavals( It were discs of (Beta Naphthoxy acetic acid ) 50\% from the production of Green river company . India ) (100, 200 and 300) $\mathrm{mg} / \mathrm{L}$ and Tall-Prolong ( Material wax contain Etokscouine $10 \%$ + di-2-pmenthenne $90 \%)(1,2$ and 3)\% after 60 days from full bloom stage. The trees watered every five days, and fertilized by Nitrogenous and phosphatic in two periods in March and May of each year at a rate of $500 \mathrm{~g}$. per tree, as well as by manure for the two years. The experiment included 10 treatments with three replicates. It is adopted according to Randomized Complete Block Design (RCBD), and the results were statistically analyzed according to LSD test at the probability level of 5\% [5]. Trees spraying was done early morning until wetness was full addendum. Tween 20 was added at conc. of $1 \mathrm{~cm} 3 / \mathrm{L}$ as spreader material .Ten normal fruits were taken at random after 95 days from full bloom from each tree for quality determination. leaf aria $\mathrm{cm}^{2}$, Total chlorophyll mg / 100g dray weight, Shoot length $\mathrm{cm}$, \% Fruit drop, Length of fruit $(\mathrm{cm})$, diameter of fruit $(\mathrm{cm})$, weight of fruit $(\mathrm{gm})$ and percentage humidity of fruits according to [8]. Firmness was measured on two sides of each fruit with an Effegi penetrometer (Model NI, McCormick Fruit Tech ,Yakima ,WA) Fitted with an $11.1 \mathrm{~mm}$ tip. The percentage of cracking were calculated during the months of Jun and July for season according to [11]. The total soluble solids were determined by hand refractometer. Total acidty $\%$ and Vitamin $\mathrm{C}$ $\mathrm{mg} / 100 \mathrm{ml}$ Juice according to [15]. Calcium pictate was determined according to [17].

\section{Results and discussion}

1-Effect of spraying with Grofalcs, Stavals and Tall-Prolong on leaf aria, total chlorophyll, shoot length, length, diameter, weight, firmness, Calcium pictate and humidity of fruits .

Spraying with Grofalcs, Stavals and TallProlong led to increased in the leaf aria, total chlorophyll, shoot length, length, diameter, weight, firmness ,Calcium pictate and humidity of fruits significantly compared to control treatment until reached highest rates $\left(32.98 \mathrm{~cm}^{2}, 118.75 \mathrm{mg} / 100 \mathrm{~g}\right.$ dry weight ,14.22 cm,5.93 cm, $4.93 \mathrm{~cm}$, $90.08 \mathrm{gm}, 9.15 \mathrm{~kg} / \mathrm{cm}^{2}, 3.99 \%$ ) in the treatment Grofalcs $400 \mathrm{mg} / \mathrm{L}$ in comparison to the lowest values $\left(26.12 \mathrm{~cm}^{2}, 113.21 \mathrm{mg} / 100 \mathrm{~g}\right.$ dry weight, $10.18 \mathrm{~cm}, 4.29 \mathrm{~cm}, 3.40 \mathrm{~cm}, 85.76 \mathrm{gm}, 8.32 \mathrm{~kg} / \mathrm{cm}^{2}$, $85.90 \%$ and $2.96 \%$ ) in control treatment , respectively. The highest rates of humidity of fruits in the treatment Tall-Prolong $3 \%$ it was $87.44 \%$ (Table1 and 2). The increase in leaf aria, total chlorophyll, shoot length, length, diameter, weight, firmness, Calcium pictate and humidity of fruits because of the treatment of Grofalcs , Stavals and Tall-Prolong due to the fact that auxins and gibberellins work as center to aggregation nutrient materials and enhancing the speed of transferring materials from leaves to fruits [9]. The increase in firmness in fruits due to spraying trees with auxins and gibberellins because these treatments plays an important role in strengthening the cell walls through its role in enhancing pectin coherence which increases the thickness of cell walls, which makes it more strength and stiffness to resist pectin analysis enzymes [13]. Besides that increasing in the fruit length, cell size, leaf aria, total chlorophyll were obtained due to the treated of effect. This act leads to enhance the photosynthesis process and transfer materials to fruits and in large increase in total growth. The waxed materials leads reduction in fruit respiration which finely to lead to decrease the stored materials in fruits $[14,6]$.

2- Effect of spraying with Grofalcs, Stavals and Tall-Prolong on percentage of fruit drupe, percentage of cracking, T.S.S, acidity and Vitamin C .

Data in Table ( 1 and 2 ) shows that percentage of fruit drop, percentage of cracking, total soluble solids ( T.S.S ), acidity and Vitamin C, in fruits were decreased insignificantly when trees sprayed with Grofalcs, Stavals and Tall-Prolong. The highest significance result were recorded in control treatment, that gave the highest percentages of fruit drop, percentage of cracking, total soluble solids , acidityand Vitamin C, they were $(17.43 \%, 10.56 \%$, $11.80 \%, 1.07 \%$ and $7.55 \mathrm{mg} / 100 \mathrm{ml}$ Juice) comparison with lest rates of percentages of fruit drupe and percentage of cracking ( $6.68 \%$ and 2.95 ) in Stavals $300 \mathrm{mg} / \mathrm{L}$ and Grofalcs $400 \mathrm{mg} / \mathrm{L}$ treatments respectively. The lest rates of percentages total soluble solids, acidityand Vitamin C, they were $(11.20 \%, 17.70 \%, 0.80 \%$ and $7.01 \mathrm{mg} / 100 \mathrm{ml}$ 


\section{Impact Factor:}

\begin{tabular}{|c|c|c|}
\hline (India) & $=1$ & SIS (USA) = \\
\hline & & РИНЦ $($ Russia $)=$ \\
\hline & & ESJI $(\mathrm{KZ}) \quad=$ \\
\hline IF & $=1.500$ & SJIF $($ Morocco $)=\mathbf{2 . 0 3 1}$ \\
\hline
\end{tabular}

Juice) in control treatment, respectively. The decreasing in the fruit dropping percentage due to auxins spraying could be attributed for prevention cell wall middle lamella analysis in abscission zone through decreasing the action of ethylene, peroxidase and IAA- Oxidase enzymes which resulted in the physiological analysis occurring to the cell wall. Meanwhile the decreasing in cracking percentage due to gibberellins spraying could be attributed to the increase in plasticity and elasticity of fruit peel that carried on with internal fruit growth, besides, its role in cell extension and increasing photosynthesis products that has big necessary importance in building cell wall, and strength to protect fruit from [13]. The reduction in total soluble solids, acidity and Vitamin C due to the sprayed with Grofalcs, Stavals and Tall-Prolong return to the increase in the percentage of fruit water contents which intern reducing the concentration of materials in fruit juice.

Table 1

Effect of spraying with Grofalcs, Stavals and Tall-Prolong on physical and chemical characters fruits of local apple cv. Sharaby for season 2014 .

\begin{tabular}{|l|c|c|c|c|c|c|c|}
\hline Treatments & $\begin{array}{c}\text { leaf aria } \\
\mathrm{cm}^{2}\end{array}$ & $\begin{array}{c}\text { Total } \\
\text { chlorophyl } \\
\text { l mg / 100g }\end{array}$ & $\begin{array}{c}\text { Shoot } \\
\text { length } \\
\text { cm }\end{array}$ & $\begin{array}{c}\text { \% Fruit } \\
\text { drop }\end{array}$ & $\begin{array}{c}\text { Length of } \\
\text { fruit cm }\end{array}$ & $\begin{array}{c}\text { Diameter of } \\
\text { fruit cm }\end{array}$ & $\begin{array}{c}\text { weight of } \\
\text { fruit gm }\end{array}$ \\
\hline \multicolumn{1}{|c|}{ Control } & 26.12 & 113.21 & 10.18 & 17.43 & 4.29 & 3.40 & 85.76 \\
\hline Grofalcs 200 mg / L & 28.34 & 114.90 & 11.29 & 14.19 & 4.95 & 4.70 & 87.55 \\
\hline Grofalcs 300 mg / L & 31.56 & 116.59 & 13.78 & 10.67 & 5.20 & 4.87 & 90.08 \\
\hline Grofalcs 400 mg / L & 32.98 & 118.75 & 14.22 & 8.55 & 5.93 & 4.98 & 93.25 \\
\hline Stavals 100 mg / L & 28.11 & 114.43 & 10.87 & 13.20 & 4.38 & 4.65 & 86.90 \\
\hline Stavals 200 mg / L & 29.70 & 115.36 & 11.09 & 9.32 & 4.53 & 4.79 & 87.65 \\
\hline Stavals 300 mg / L & 31.24 & 115.90 & 11.45 & 6.68 & 4.90 & 4.85 & 88.99 \\
\hline Tall-Prolong 1\% & 26.90 & 113.84 & 10.50 & 16.21 & 4.34 & 4.53 & 87.00 \\
\hline Tall-Prolong 2\% & 26.98 & 113.93 & 10.48 & 15.00 & 4.38 & 4.55 & 86.40 \\
\hline Tall-Prolong 3\% & 26.97 & 113.95 & 10.61 & 15.36 & 4.40 & 4.54 & 86.96 \\
\hline L. S. D. 0.05 & 0.54 & 0.61 & 0.23 & 1.20 & 0.79 & 0.36 & 2.12 \\
\hline
\end{tabular}

Table 2

Effect of spraying with Grofalcs, Stavals and Tall-Prolong on physical and chemical characters fruits of local apple cv. Sharaby for season 2014 .

\begin{tabular}{|c|c|c|c|c|c|c|c|}
\hline Treatments & $\begin{array}{c}\text { firmness } \\
\text { of fruit } \\
\mathrm{kg} / \mathrm{cm}^{2}\end{array}$ & $\begin{array}{c}\% \\
\text { cracking }\end{array}$ & $\begin{array}{c}\% \\
\text { humidity } \\
\text { of fruits }\end{array}$ & $\begin{array}{c}\% \text { Total } \\
\text { soluble } \\
\text { sold }\end{array}$ & Acidity & $\begin{array}{c}\text { Vitamin C } \\
\text { calcium } \\
\text { pictate }\end{array}$ \\
\hline Control & 8.32 & 10.56 & 85.90 & 11.80 & 1.07 & 7.55 & 2.96 \\
\hline Grofalcs 200 mg / L & 8.50 & 7.15 & 86.81 & 11.30 & 1.01 & 7.18 & 3.59 \\
\hline Grofalcs 300 mg / L & 8.53 & 6.22 & 86.96 & 11.12 & 0.93 & 7.15 & 3.82 \\
\hline Grofalcs 400 mg / L & 9.15 & 2.95 & 87.23 & 10.93 & 0.87 & 7.02 & 3.91 \\
\hline Stavals 100 mg / L & 8.49 & 8.37 & 86.49 & 11.40 & 0.98 & 7.14 & 3.17 \\
\hline Stavals 200 mg / L & 8.52 & 6.60 & 86.74 & 11.31 & 0.85 & 7.10 & 3.19 \\
\hline Stavals 300 mg / L & 8.61 & 6.03 & 86.95 & 11.25 & 0.81 & 7.07 & 3.54 \\
\hline Tall-Prolong 1\% & 8.50 & 8.19 & 86.90 & 11.39 & 0.97 & 7.16 & 3.00 \\
\hline Tall-Prolong 2\% & 8.64 & 6.50 & 87.19 & 11.27 & 0.88 & 7.10 & 3.15 \\
\hline Tall-Prolong 3\% & 8.70 & 3.83 & 87.44 & 11.20 & 0.80 & 7.01 & 3.28 \\
\hline L. S. D. 0.05 & 0.15 & 2.09 & 0.95 & 0.11 & 0.06 & 0.08 & 0.22 \\
\hline
\end{tabular}

\section{Conclusion}

It could be concluded from this experiment that, spraying trees with Grofalcs, Stavals and TallProlong led to increased the leaf aria, total chlorophyll, shoot length, length, diameter, weight, firmness, Calcium pictate and percentage humidity of fruits. Also reduced percentage of fruit drop, percentage of cracking, T.S.S, acidity and Vitamin $\mathrm{C}$ of fruits in maturity stage compared with control treatment. 


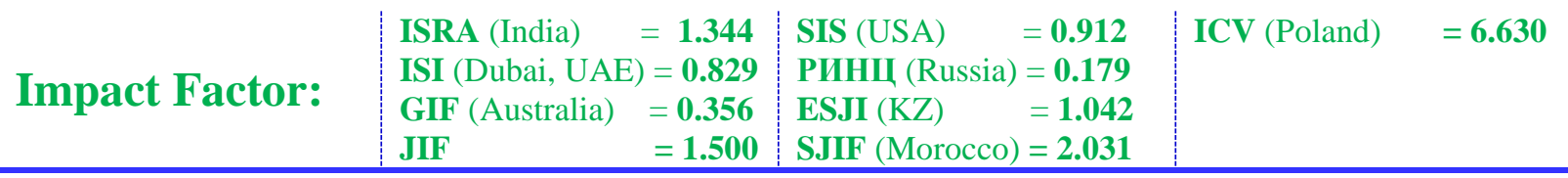

\section{References:}

1. Abo-Zaid AN (2000) Plant Hormones and Application Agricultural. Arabic home for putolishing . Cairo.

2. Al-Dulaimi RM (1999) Influence of some Factors effection on the splitting of pomegranate fruits. Ph. D. Thesis . Dep. Hort. Agric. Colle. Univ. of Baghdad . Iraq .

3. AL-Ebraheme AA (2013) Effect of spraying with Stavals and castor oil on quality of local apple cv. Read summer tress. Journal of Babylon. 2 (21 ): 694-698.

4. Al-Rawi AZD (1999) Effect of the treatment with NAA and GA3 on fruit abscission and quality of fig cv. Asowd Diala ( Ficus carica L.). Ph. D. Thesis. Dep. Hort. Agric. Colle. Univ.of Baghdad .Iraq.

5. AL-Rawi KM, Khalf Allah AM (2000) Design and Analysis of Agricultural Experiments . College of Agric. Deciduous Fruit, Growth and Production.

6. AL-Shmery GN (2014) Storage Technology Of Horticultural Crops. Univ. Deyala . Iraq .

7. AL-Shmery WM (2013) Effect of NAA , GA3 on physical and chemical characteristics of local apple fruits. J. AL-Kufa Univ. For Biology . 2012.4 (2) : 177 - 122.

8. Ibrahim HM (2010) Deciduous Fruit, Growth and Production . College of Agric. Univ. Alex. Egypt.

9. Jundi HM (2003) Physiology of tree fruits. Arabic home for putolishing. Cairo.

10. AL-Hamdawi AM, Ali HJ, AL-Mousawy NS (2014) Effect of pruning and spraying Grofalcs and Zeatin on some vegetative growth and yield, and its quality of fig tree cv. "Waziri" (Ficuscarica L.). International Journal for
Sciences and Technology ( IJST ). 2014 .9(2): 7-11.

11. AL-Hamdawi AM, AL-Numani RM (2012) Effect of Pruning and spraying with Paclobutrazol and Zinc sulphate on fruits quality of fig cv. AsowdDialaand percentage of cracking. The international Journal for Sciences and Technology ( IJST ). 2012 . 7 ( 4 ) : $5-10$.

12. AL-Numani RM (2013) Effect of Salicylic acid and Grofalcs on physical and chemical characteristics of local apple fruits) Maluspumila M . ). J . ALphrat of Agricultural Scions. 5 ( 1 ): $34-39$.

13. Byers RE, Carbough HD (1995) Chemical, Cultural and physiological factors influencing Stayman fruit cracking . Virginia polytechnic Institute and State University Bulletin . 95 (1) : 1-33.

14. Cantillano R (1984) Effect of use of polyethylene film liners and an antitranspirant in the storage of apples cultivar Golden Delicious. Agropecuaria. S. A. $13: 818-835$.

15. Ranganna S (1977) Manual of analysis of fruit and vegetable products . Tata . McGraw. Hill publishing Co . New Delhi .

16. Singh RP, Sharma YP, Awasthi RP (1993) Influence different cultural practices on premature fruit cracking of pomegranate. Progressive . Hort., 22 (1-4) . (C. F. Hort. Abst. 1995 .Vol. 63 . No. 7148) .

17. Rouhani I, Bassiri A (1976) Changes in the physical and chemical characteristics of Shahani dates during development and maturity. Hort. Sci . $15: 480-498$. 